\title{
Editorial: A Peach is a Peach is a Peach
}

You have not seen the binding or the printing or the pages, carefully cut by the purchaser's own paper-knife, and now browning at the crinkles, but you would know from the title of the book and the title of the series, and from the manner of designating the author and the publisher, that a book recently bought for $80 p$ in a country bookshop in Shropshire was not a recent production. It is Contemporary Thought of Great Britain, by Alban G. Widgery, M.A., Stanton Lecturer in the Philosophy of Religion in the University of Cambridge, published by Williams and Norgate Limited, I4 Henrietta Street, Covent Garden, WC2, in their Library of Contemporary Thought (General Editor: W. Tudor Jones, M.A., Ph.D.). The books in the series are offered as 'Uniformly Bound Cloth, 5 s. net each volume'. Mr Widgery signed his preface in July of the same year as the book was published-another sign that the work dates from a distant epoch when the pace of life was faster than it is today.

The date is 1927 , sufficiently close to the foundation of this Institute and the inauguration of this journal to have a special interest to add to the general interest that there always is in seeing what someone of sixty years ago thought about things as they were sixty years ago. He was a very modern minded young man:

It will be understood that it is not from any discourtesy that in order to avoid the continual repetition of 'Lord' so and so and 'Sir' so and so, 'Professor' this and 'Dr.' that, all such titles have been omitted. The practice here adopted, of a general limitation to plain names, is not an unknown one when reference is to men of eminence. In a short treatise such as this many thinkers of outstanding merit have had to be omitted in order that the main issues should not be confused by the further curtailing of discussions already too brief.

The main issues are labelled in the chapter headings as Naturalism, Absolute Idealism, Pragmatist Humanism, Realism and Theism. Lord Soand-So may be Lord Balfour or Lord Haldane; Sir So-and-So Such-andSuch is possibly Sir Oliver Lodge; Professor Sorley and Professor Taylor, Dr McTaggart and the lively young Dr Broad are among the Thises and the Thats. Many of the names in the index occur in the lists of our founding fathers and early Council members and individual members of the Institute. But Mr Widgery's subject was thought, not just philosophy, and he gives space to Thomas Hardy and H. G. Wells, G. K. Chesterton and 
Dean Inge, Middleton Murry and Bernard Shaw. Every generation has the Modern Masters it deserves.

The author is conscious of change but not decay in all around he sees. He welcomes the beginning of the end of idealist dominance-'Extreme philosophical idealism is not native to the British mind'-and is proud of his university as well as his country. Even in its heyday, Idealism had its main strongholds in Oxford and Glasgow, while 'At Cambridge the prevailing attitude was, as usual, distinctly critical, and as represented by Henry Sidgwick was one of non-committal'. (In 1927 that hyphenated adjective was also a hyphenated noun.) He looks kindly on the rise of Realism that was in progress in his decade, and the influences that were 'leading away from the consideration of the nature of the Whole to the investigation of details', and he has a good eye for a picturesque or poetic particular, as in a passage where he is arguing that Theistic eclecticism must recognize an inescapable pluralism in its description of the world:

It has to acknowledge realities, facts and values of all types. It is not able to find significant relationships between them all. There does not appear to be any significant relation, for example, between the taste of a fine peach, a symphony of Beethoven, the imbecilities of a lunatic, the beauty of Cleopatra, the crime of Dr. Crippen, the courage of Nelson, and the devotions of St. Thomas à Kempis.

The name of Wittgenstein occurs nowhere in the book, in spite of its Cambridge origin, its particularism and its forward-looking temper. The news of the publication of the Tractatus in 1922 had not crossed the street from Trinity to the Divinity School. But there is one phrase that is a pleasing anticipation of what was to come in the next decade:

Whether Realism must eventually come to acknowledge ultimate conceptions concerning the unity and significance of experience or be doomed to lose the threads of intelligibility in a maze of existent particlars and of subsistent universals must remain to be seen. For the present it appears to be engaged not merely in pulling down the houses of cards which earlier system-makers have built up, but even in tearing the cards into the largest possible number of individual pi eces. 